Vol. 14(14), pp. 1181-1185, 8 April, 2015

DOI: $10.5897 / A J B 2014.14360$

Article Number: 986B32E52175

ISSN 1684-5315

Copyright (C) 2015

African Journal of Biotechnology

Author(s) retain the copyright of this article

http://www.academicjournals.org/AJB

\title{
Detection of Pseudomonas fluorescens from broth, water and infected tissues by loop-mediated isothermal amplification (LAMP) method
}

\author{
Pooja Saharan, Joginder S. Duhan and Suresh K. Gahlawat ${ }^{\star}$ \\ Department of Biotechnology, Chaudhary Devi Lal University, Sirsa-125 055, India. \\ Received 10 December, 2014; Accepted 25 March, 2015
}

\begin{abstract}
Loop mediated isothermal amplification is rapid, highly sensitive and specifically developed method for detection of bacterial infections. AprX gene for alkaline metalloprotease of Pseudomonas fluorescens was used to design four primers and loop mediated isothermal amplification (LAMP) conditions were standardized for amplification of DNA. LAMP primers successfully amplified $P$. fluorescens from DNA and bacterial cells taken directly from broth, water and infected tissues with high specificity and sensitivity $(10 \mathrm{pg})$ under isothermal condition at $61^{\circ} \mathrm{C}$.
\end{abstract}

Key words: Pseudomonas fluorescens, loop mediated isothermal amplification (LAMP), rapid, simple, specificity, sensitivity.

\section{INTRODUCTION}

Pseudomonas fluorescens is a member of the fluorescent pseudomonad group and (unlike Pseudomonas aeruginosa) has generally been regarded to be of low virulence and an infrequent cause of human infection (Hsueh et al., 1998). But later on, six strains grown in transfusion blood having characteristic features of $P$. fluorescens had caused severe to fatal reactions in the recipients (Pittman, 1953). Sutter (1968) also isolated $P$. fluorescens repeatedly from the blood of a patient with an abdominal abscess following bowel resection. $P$. fluorescens has been reported to cause occasional cases of transfusion-associated septicemia in blood recipients, including fatal reactions (Scott et al., 1988), and catheterrelated bacteremia in patients with cancer (Hsueh et al., 1998). P. fluorescens is an aerobic, rod shaped, Gram- negative bacteria that grows best at temperature range between 25 and $30^{\circ} \mathrm{C}$.

In 2001, P. fluorescens was also isolated from carp in the Abbassa fish farm, with a prevalence rate of $23 \%$ (Aly, 2001) while during 2002, P. fluorescens was isolated from Nile tilapia cultured in duck-fish farms at Ismailia and Sharkia Provinces with prevalence of $8 \%$ (Aly et al., 2002). In 2004, seven out of the 17 commercial fish farms in Kafr EISheikh Governorate suffered from high mortalities, ranging from 17.6 to $22.9 \%$. Bacteriological examinations revealed $36.9 \%$ fish were infected with $P$. fluorescens, $29.1 \%$ with $P$. aureginosa, $18.5 \%$ with Pseudomonas anguilliseptica and $15.5 \%$ with Pseudomonas pseudoalkaligene (Masbouba, 2004).

\footnotetext{
*Corresponding author. E-mail: skgcdlu@gmail.com. Tel: +91 9896342891. Fax: +91 1662248123.
}

Author(s) agree that this article remains permanently open access under the terms of the Creative Commons Attribution License 4.0 International License 
Eissa et al. (2010) isolated different strains of $P$ seudomonas species namely Pseudomonas putida, $P$. aeruginosa, $P$. fluorescens and $P$. anguilliseptica from Oreochromis niloticus in Qaroun and Wadi-El-Rayan Lakes, Egypt. They reported that infected fishes showed irregular hemorrhages on body surface, especially at the ventral part of abdomen, eyes cloudiness, scales detachment and congested gills were observed. Internally, there were sanguineous fluids in the abdominal cavity of some fish. Also, these results are in agreement with those of EL-Hady and Samy (2011) who isolated $P$. putida, $P$. aeruginosa, $P$. fluorescens and $P$. anguilliseptica from cultured $O$. niloticus and Cyprinus carpio from different fish farms at different localities in Egypt. This data clearly indicates that infection is responsible for huge losses to aquaculture.

Pseudomonas spp. causes septicaemia in aquatic animals (Roberts, 1978) and a number of aquatic animals including fish, frogs and soft-shelled turtles are reported to be susceptible to Pseudomonas spp. with moderate to high losses (Somsiri and Soontornvit, 2002). Pseudomonas spp. bacteria are considered as opportunistic indoor pathogens as their infection initiates an inflammatory response (Hirvonen et al., 2005; Huttunen et al., 2003). Bacteria invades the host tissue and cause infection and bacteremia in immunocompromised hosts (HIV/AIDS, cystic fibrosis, bronchiectasis, severe chronic obstructive pulmonary disease, burns, malignancy or diabetes mellitus) (Feldman et al., 1998; Liu and Mercer, 1963). Identification of $P$. fluorescens is very tedious as it is not a frequent cause of human infections; prefers versatile environments (like water, soil, foods, etc.) and grow poorly at the standard hospital microbiology incubation temperature of approximately $36^{\circ} \mathrm{C}$ (Weyant et al., 1996; CDC, 2005).

Detection of $P$. fluorescens by standard plate count method, polymerase chain reaction (PCR) and RT-PCR is time consuming and also such methods require the use of special equipments. On the other hand, loop mediated isothermal amplification (LAMP) (Notomi et al., 2000; Nagamine et al., 2002) is simple, easy, rapid and costeffective method which have been widely used for the diagnosis of bacteria (Gahlawat et al., 2009; Chen at al., 2011; Han et al., 2011; Saharan et al., 2014a), viruses (Wang et al., 2011; Zhao et al., 2011; Saharan et al., 2014b) and parasites (lkadai et al., 2004; Iseki et al., 2007; Lu et al., 2011). Seeking the benefits of LAMP method, the present study is planned to determine application of LAMP assay for rapid detection of $P$. fluorescens from DNA and bacterial cells taken directly from broth, water and infected tissues.

\section{MATERIALS AND METHODS}

\section{Bacterial strains}

Aeromonas hydrophila (MTCC 646), Lactobacillus acidophilus(MTCC 447), P. flourescens (MTCC 7200), Staphylococcus aureus
(MTCC 87) and Bacillus cereus (MTCC 6728) were purchased from Microbial Type Culture Collection (MTCC) and Gene Bank, Institute of Microbial Technology Chandigarh (India) in the lyophilized form. The lyophilized cultures were revived in nutrient broth and cultured on nutrient agar plates. After $24 \mathrm{~h}$ of incubation at $28 \pm 2^{\circ} \mathrm{C}$, the bacteria were resuspended in nutrient broth for the isolation of genomic DNA.

\section{Test sample}

Clarius batracus (10-12 cm in length) were collected from local pond and kept in aquarium of $50 \mathrm{~L}$ capacity in 1:1 ratio of tap water: pond water. Fish were challenged by adding $P$. fluorescens broth in aquarium water (approximately 1:100 ratio). Mucus, kidney and water samples were collected after $24 \mathrm{~h}$ and stored at $-20^{\circ} \mathrm{C}$. Further genomic DNA was isolated from these samples.

\section{Genomic DNA extraction from bacterial broth, pond water and infected tissue}

Genomic DNA was isolated from five bacterial strains ( $P$ fluorescens, A. hydrophila, L. acidophilus, S. aureus and B. cereus) grown in nutrient broth overnight, pond water, mucus and kidney tissue (isolated from infected fish crushed in liquid nitrogen) using Qiagen DNA extraction kit (Gentra Puregene protocol, 2010) according to the manufacturer's instructions.

\section{Design of oligonucleotide primers for LAMP method}

Pseudomonas sp. strains high in proteolytic activity in milk are responsible for bacterial deterioration of dairy products. Protease digestion of milk can lead to clotting and gelation of milk casein. So, a rapid test for detection of Pseudomonas strains in milk is required because conventional plate-counting procedure to detect psychrotrophic contamination in milk products is time-consuming and not useful to prevent food degradation. The apr $X$ gene encoding an alkaline metalloprotease is considered the responsible agent for milk spoilage. LAMP primers targeting for this sequence can accelerate the detection process. Hence, DNA sequence of $P$. fluorescens $\mathrm{Apr} X$ gene for alkaline metalloprotease, was retrieved (partial sequence) from NCBI (http://www.ncbi:nlm.nhi.gov/) and used for primer designing. The specific LAMP DNA oligonucleotide primers were designed by using Eiken Genome site via free online software, that is, Primer-Explorer IV software program (http://loopamp.eiken.co.jp/e/lamp/). Four sets of primers (described in detail below) based on the following six distinct regions of the target gene: the $\mathrm{F} 3 \mathrm{c}, \mathrm{F} 2 \mathrm{c}$ and $\mathrm{F} 1 \mathrm{c}$ regions at the 3 side and the B1, B2 and B3 regions at the $5^{\prime}$ side were designed (Table 1) and got synthesized from Sigma Aldrich.

\section{Optimization of LAMP protocol}

Bacterial DNA of $P$. fluorescens was amplified by using the following composition of LAMP reaction mixture: $7.5 \mu \mathrm{l} 1 \mathrm{x}$ Thermopol buffer [10 mM KCl, $10 \mathrm{mM}\left(\mathrm{NH}_{4}\right)_{2} \mathrm{SO}_{4}, 20 \mathrm{mM}$ Tris- $\mathrm{HCl}$, $2.0 \mathrm{mM} \mathrm{MgSO}$, $0.1 \%$ Triton X-100; New England Biolab], $4 \mu \mathrm{l}$ Betaine (0.8 M Sigma), $1.0 \mu \mathrm{l}$ dNTPs (1.0 mM; Sigma), $0.5 \mu \mathrm{l}$ each of $\mathrm{F}_{3}$ and $\mathrm{B}_{3}$ (0.2 mM; Sigma), $4.0 \mu \mathrm{l}$ each of FIP and BIP (1.6 mM; Sigma), $1.0 \mu \mathrm{l}$ Bst DNA polymerase (8U; New England Biolab), 0.5 $\mu \mathrm{l}$ nuclease free water and $2.0 \mu \mathrm{l}$ DNA template. The reaction was carried out at different temperatures ranging from 60 to $65^{\circ} \mathrm{C}$ for $1 \mathrm{~h}$ followed by heat inactivation step at $80^{\circ} \mathrm{C}$ for 5 min in Accublock digital dry bath (Labnet International Inc.). The samples were kept in ice for $10 \mathrm{~min}$. 
Table 1. Details of primers used for LAMP assay.

\begin{tabular}{cllc}
\hline S/N & Oligo name & 5'<----Sequence----->3' & Length \\
\hline 1 & F3 & TCGAGCACCATGAACAAACA & 20 \\
2 & B3 & GGCAGGTAAGCGAAGGC & 17 \\
3 & FIP & AGGATTGCATGGCCAGTGCGCCGGGTTCAGCCAGTTC & 37 \\
4 & BIP & CGGACGTGGCCAACGTGACGCTGTAGTTGCCGAAAGTC & 38 \\
\hline
\end{tabular}

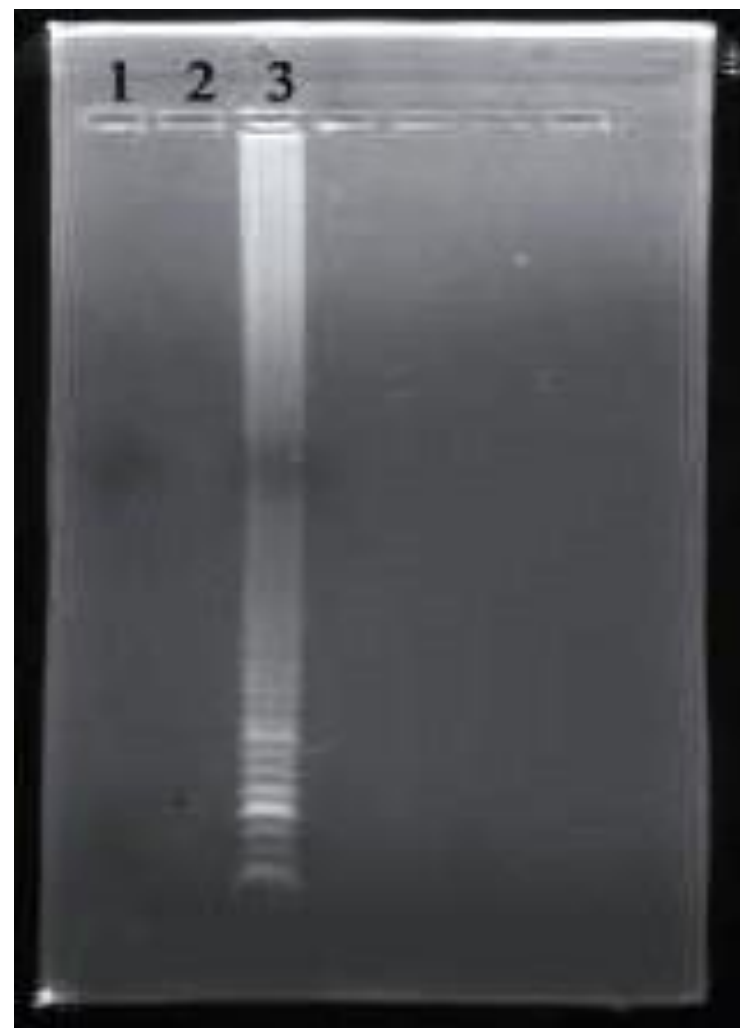

Figure 1. Agarose gel illustrating the amplification of the designed primers to the $P$. fluorescens DNA. The reaction was carried out at $61^{\circ} \mathrm{C}$ using the 4 primer set for $1 \mathrm{~h}$ followed by heat inactivation step at $80^{\circ} \mathrm{C}$ for 5 to 7 min. Lanes: 1 , negative control; 2 , empty; $3, P$. fluorescens DNA showing good amplification (ladder like band pattern).

\section{Visualization of LAMP product}

The amplified products were analyzed in $2.0 \%$ agarose gel in Tris Borate EDTA (1x) buffer stained with ethidium bromide and photographed using the Bio Red gel documentation and analysis system $(X R)$.

\section{Specificity test}

The ability of LAMP assay developed for detection of $P$. fluorescens specifically was evaluated by using different bacterial DNA viz. P. fluorescens, L. acidophilus, A. hydrophila, S. aureus and $B$. cereus. The specificity of the LAMP was determined on the basis of DNA amplification.

\section{Sensitivity test}

DNA of $P$. fluorescens was serially diluted up to $10^{-10}$ dilutions with nuclease free water and lower detection limit was tested.

Detection of $P$. fluorescens in broth, pond water, infected tissue and mucus samples

Bacterial broth, pond water, mucus and infected crushed kidney tissue samples of fish were used to check the potential of LAMP method to amplify nucleic acid directly from live cells of $P$. fluorescens. Finally, LAMP assay was performed with these test samples under optimized conditions.

\section{RESULTS AND DISCUSSION}

LAMP method successfully detected $P$. fluorescens DNA as ladder like pattern on gel after isothermal amplification by Bst polymerase.

\section{Optimization of LAMP reaction conditions for $P$. fluorescens}

$P$. fluorescens DNA was tested under different conditions of temperature and time, that is, 60 to $65^{\circ} \mathrm{C}$ for $1 \mathrm{~h}$ followed by heat inactivation step at $80^{\circ} \mathrm{C}$ for 5 to $10 \mathrm{~min}$ in order to determine best amplification reaction conditions. Results show that optimum temperature and time for amplification of $P$. fluorescens DNA was found to be $61^{\circ} \mathrm{C}$ for $60 \mathrm{~min}$ and $80^{\circ} \mathrm{C}$ for 5 to $7 \mathrm{~min}$ (Figure 1) and no amplification was observed in negative control. While at other temperatures, very poor (smear like band pattern at $63^{\circ} \mathrm{C}$ ) or no amplification was observed (Gahlawat et al., 2009). Fernandez-Soto et al. (2014) detected Schistosoma mansoni by using Loopamp DNA amplification Kit tested with the $S$. mansoni primer set and found that LAMP reaction successfully take place at temperatures of 61,63 and $65^{\circ} \mathrm{C}$ within the temperature range $\left(60-65^{\circ} \mathrm{C}\right)$. Similarly, Uemura et al. (2008) detected Pneumocystis pneumonia by using LAMP assay at $61^{\circ} \mathrm{C}$ temperature.

\section{Specificity of LAMP assay for $P$. fluorescens}

DNA samples of $P$. fluorescens, $L$. acidophilus, $A$. hydrophila, $S$. aureus and $B$. cereus were tested for 


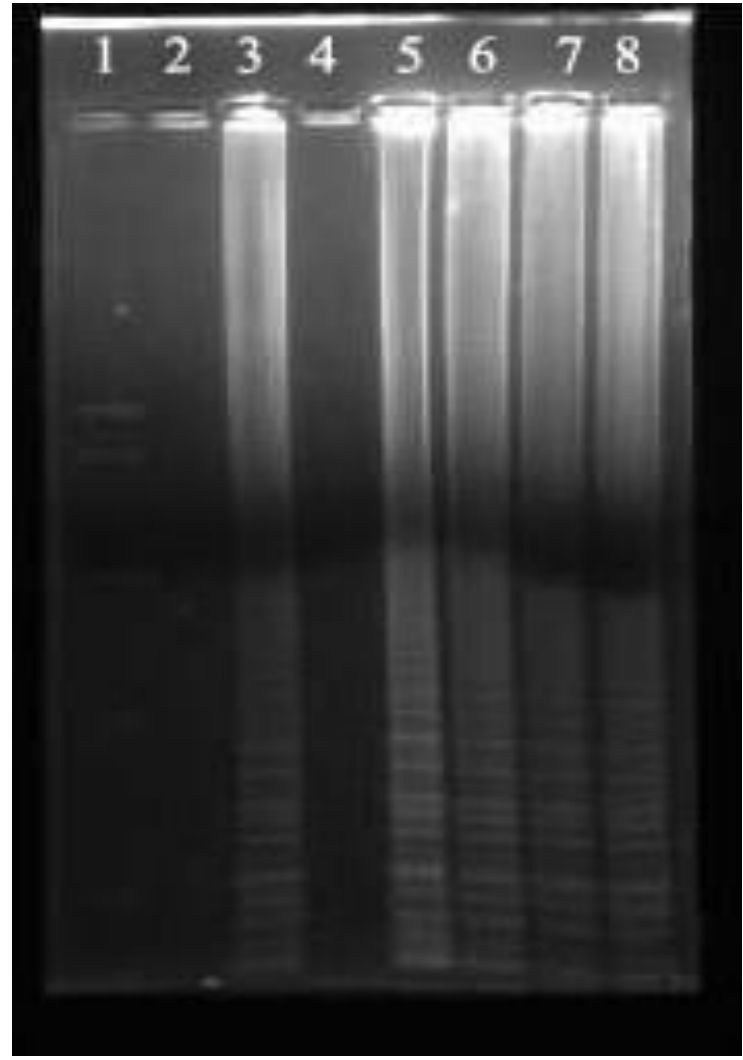

Figure 2. Agarose gel illustrating the direct detection of bacteria from collected field samples infected with $P$. fluorescens by LAMP method. The reaction was carried out at $61^{\circ} \mathrm{C}$ using the 4 primer set for $1 \mathrm{~h}$. Lanes: 1, DNA ladder (100 bp); 2, negative control; 3, positive control ( $P$. fluorescens DNA); 4, kidney tissue; 5: DNA isolated from infected tissue; 6 , pond water sample; 7, DNA isolated from infected pond water; 8, DNA isolated from test water infected with mixture of pathogenic bacteria.

specificity of the LAMP product. LAMP assay specifically amplified only sequence of the target, that is, DNA of $P$. fluorescens only while no amplification was observed with DNA samples from other bacterial strains (B. cereus, $A$. hydrophila, S. aureus and L.acidophilus) (Figure not shown). Also, LAMP assay effectively detected only $P$. fluorescens DNA from mixture of DNA isolated from test water infected with mixture of pathogenic bacteria (Figures 2 Lane: 8). Specificity of LAMP method was justified by use of four different primers for recognizing six distinct sequences on target gene. LAMP primers were found to be highly specific to the Apr $X$ gene for alkaline metalloprotease because they did not attach to other bacterial DNA sequences. The specificity of LAMP assay was observed by the absence of any cross reaction with other tested bacterial strains indicating a high specificity when among 116 reference strains, only methicillin-resistant $S$. aureus was detected by orf $X$ LAMP assay (Su et al., 2014).

\section{Sensitivity limit of LAMP}

The detection limit of LAMP assay was tested with serially diluted DNA samples of $P$. fluorescens. Samples were tested up to $10^{-10}$ dilution and last detection limit of LAMP was found to be approximately $10 \mathrm{pg}$ according to dilution (Figure not shown). Similar sensitivity was reported by Pan et al. (2011) in Brucella species.

In sensitivity evaluations, Hui et al. (2013) successfully detected a serial dilution of extracted Bordetella bronchiseptica DNA with a detection limit of 9 copies, which was 10 times more sensitive than that of PCR. He also considered that there is no need for the complex instrumentation making this LAMP assays a promising alternative for the diagnosis of $B$. bronchiseptica in rural areas and developing countries where there is lack of complex laboratory services.

\section{Direct detection of $\boldsymbol{P}$. fluorescens from bacterial broth, pond water, tissue and mucus}

LAMP assay was also found an to be an effective tool for the detection of $P$. fluorescens bacteria directly from field samples, that is, pond water and infected kidney tissue of fish (Figure 2). Although there are very few reports related to direct detection of bacteria from broth, water as well as from infected tissue by using LAMP method (Iwamoto et al., 2003; Savan et al., 2004; Poon et al., 2006; Kubota et al., 2008; Gahlawat et al., 2009) but still, this method may prove useful for direct detection of bacteria from the sites of infection and thus can be helpful in field testing. However, this method can detect $P$. florescens DNA from kidney tissue easily (Figure 2). So, LAMP can directly detect the bacteria from pond water and tissue samples and thus, it can be used as valuable tool for easy and robust on-the-spot detection of this bacterium in clinical laboratories and field conditions.

\section{Conflict of interests}

The authors did not declare any conflict of interest.

\section{ACKNOWLEDGEMENTS}

The authors are thankful to UGC, New Delhi for providing them with financial support under major research project and authorities of Chaudhary Devi Lal University, Sirsa, India for providing laboratory facilities.

\section{REFERENCES}

Aly S (2001).Light and electron microscopic studies on pseudomoniasis among common carp (Cyprinus carpio).Suez Canal Vet. Med. J. 4: $95-103$.

Aly S, El-Attar A, El-Genedy H (2002). Role of fish in transmission of 
Pseudomonas fluorescens to ducklings with a trial for treatment and control. Pathologic \& Electron Microscopic Examinations, $10^{\text {th }}$ Scientific Vet. Med. Conference, Assuit Univ.17 -19 December, 187208.

CDC (2005). Pseudomonas bloodstream infections associated with a heparin/saline flush-Missouri, New York, Texas, and Michigan, 20042005. Morb. Mortal. Wkly Rep. 54: 269-272.

Chen J, Ma X, Yuan Y, Zhang W (2011).Sensitive and rapid detection of Alicyclobacillus acidoterrestris using loop-mediated isothermal amplification. J. Sci. Food Agric. 9:1070.

Eissa NME, Abou El-Ghiet EN, Shaheen AA, Abbass A (2010). Characterization of Pseudomonas species Isolated from Tilapia "Oreochromis niloticus" in Qaroun and Wadi-El-Rayan Lakes, Egypt Glob. Vet. 5 (2): 116-121.

El-Hady MA, Samy AA (2011). Molecular typing of Pseudomonas species isolated from some cultured fishes in Egypt.Global Veterinaria. 7 (6): 576-580.

Feldman M, Bryan R, Rajan S, Scheffler L, Brunnert S, Tang H, Prince A (1998).Role of flagella in pathogenesis of Pseudomonas aeruginosa pulmonary infection. Infect. Immun. 66(1):43-51.

Fernandez-Soto P, Gandasegui Arahuetes J, Sanchez Hernandez A, Lopez Aban J, Vicente Santiago B, Muro A (2014). A Loop-Mediated Isothermal Amplification (LAMP) Assay for Early Detection of Schistosoma mansoni in Stool Samples: A Diagnostic Approach in a Murine Model. PLoS Negl. Trop. Dis. 8(9): e3126.

Gahlawat SK, Ellis AE, Collet B (2009).A sensitive loop-mediated isothermal amplification (LAMP) method for detection of Renibacterium salmoninarum, causative agent of bacterial kidney disease in Salmonids. J. Fish Dis. 32:491.

Han HJ, Jung SJ, Oh MJ, Kim DH (2011).Rapid and sensitive detection of Streptococcus iniae by loop-mediated isothermal amplification (LAMP). J. Fish Dis. 34:395.

Hirvonen MR, Huttunen K, Roponen M (2005). Bacterial strains from moldy buildings are highly potent inducers of inflammatory and cytotoxic effects. Indoor Air 15(9):65-70.

Hsueh PR, Teng LJ, Pan HJ, Chen YC, Sun CC, Ho SW, Luh KT (1998).Outbreak of Pseudomonas fluorescens bacteremia among oncology patients. J. Clin. Microbiol. 36:2914-2917.

http://loopamp.eiken.co.jp/e/lamp/

http://www.ncbi:nlm.nhi.gov/

Hui Z, Zhu L, Zhou Y, Ji H, Dai H, Guo W, Xu Z (2013). Rapid and sensitive detection of Bordetella bronchiseptica by loop-mediated isothermal amplification (LAMP). Pesqui. Vet. Bras. 33(10):12221226.

Huttunen K, Hyvarinen A, Nevalainen A, Komulainen H, Hirvonen MR (2003).Production of proinflammatory mediators by indoor air bacteria and fungal spores in mouse and human cell lines. Environ. Health Perspect. 111:85-92.

Ikadai H, Tanaka H, Shibahara N, Matsuu A, Uechi M, Itoh N, Oshiro S, Kudo N, Igarashi I, Oyamada T (2004). Molecular evidence of infections with Babesia gibsoni parasites in Japan and evaluation of the diagnostic potential of a loop-mediated isothermal amplification method. J. Clin. Microbiol. 42:2465.

Iseki $\mathrm{H}$, Alhassan A, Ohta N, Thekisoe OM, Yokoyama N, Inoue N, Nambota A, Yasuda J, Igarashi I (2007).Development of a multiplex loop-mediated isothermal amplification (mLAMP) method for the simultaneous detection of bovine Babesia parasites. J. Microbiol. Methods 71:28.

Iwamoto T, Sonobe T, Hayashi K (2003). Loop-mediated isothermal amplification for direct detection of Mycobacterium tuberculosis complex, $M$. avium and $M$. intracellulare in sputum samples. J. Clin. Microbiol. 41:2616.

Kubota R, Vine BG, Alvarez AM, Jenkins DM (2008).Detection of Ralstonia solanacearum by loop-mediated isothermal amplification. Phytopathology 98:1045.

Liu PV, Mercer CB (1963).Growth, toxigenicity and virulence of Pseudomonas Aeruginosa. J. Hygiene 61: 485-491.

Lu Q, Gerrits van den Ende AH, Bakkers JM, Sun J, Lackner M, Najafzadeh MJ, Melchers WJ, Li R, de Hoog GS (2011).Identification of Pseudallescheria and Scedosporium species by three molecular methods. J. Clin. Microbiol. 49:960.
Masbouba IM (2004). Studies on Pseudomonas Infection in fish in Kafr El - Sheikh Province. Unpublished M V Sc.Thesis, Tanta University.

Nagamine K, Hase T, Notomi T (2002). Accelerated reaction by loopmediated isothermal amplification using loop primers. Mol. Cell. Probes. 16: 223.

Notomi T, Okayama $\mathrm{H}$, Masubuchi $\mathrm{H}$, Yonekawa T, Watanabe K, Amino $\mathrm{N}$, Hase T (2000).Loop-mediated isothermal amplification of DNA. Nucleic Acids Res. 28: E63.

Pan W, Wang JY, Shen HY, Zhao MG, Ju CM, Dong XY, Lin YI L, Chen DJ (2011). Development and application of the novel visual loop-mediated isothermal amplification of omp25 sequence for rapid detection of Brucella sp. J. Anim. Vet. Adv. 10 (16): 2120-2126.

Pittman M (1953). A study of bacteria implicated in transfusion reactions and of bacteria isolated from blood products. J. Lab. Clin. Med. 42(2):273-88.

Poon LL, Wong BW, Ma EH, Chan KH, Chow LM, Abeyewickreme W, Tangpukdee N, Yuen KY, Guan Y, Looareesuwan S, Peiris JS (2006). Sensitive and inexpensive molecular test for falciparum malaria: detecting Plasmodium falciparum DNA directly from heattreated blood by loop-mediated isothermal amplification. Clin. Chem. 52(2):303.

Roberts RJ (1978).Fish Pathology, 2nd ed. Bailliere Tindall, London.

Saharan P, Dingolia S, Khatri P, Duhan JS, Gahlawat SK (2014a).Loopmediated isothermal amplification (LAMP) based detection of bacteria: A Review. Afr. J. Biotechnol. 13 (19):1920-1928.

Saharan P, Khatri P, Dingolia S, Duhan JS, Gahlawat SK (2014b). Rapid detection of viruses using loop-mediated isothermal amplification (LAMP) A Review, In: Biotechnology: Prospects and Applications, edited by RK Salar, SK Gahlawat, P Siwach and JS Duhan (Springer, New Delhi, Heidelberg, New York, Dordrecht, London) 2014, 287. DOI 10.1007/978-81-322-1683-4.

Savan R, Igarashi A, Matsuoka S, Sakai M (2004).Sensitive and rapid detection of Edwardsiellosis in fish by a loop-mediated isothermal amplification method. Appl. Environ. Microbiol. 70(1):621.

Scott J, Boulton FE, Govan JR, Miles RS, McClelland DB, Prowse CV (1988).A fatal transfusion reaction associated with blood contaminated with Pseudomonas fluorescens. Vox Sang. 54:201204.

Somsiri T, Soontornvit S (2002). Bacterial diseases of cultured tiger frog (Rana tigerina). In C.R. Lavilla-Pitogo and E.R. Cruz-Lacierda (eds.), Diseases in Asian Aquaculture IV, Fish Health Section, Asian Fisheries Society, Manila.

Su J, Liu X, Cui H, Li Y, Chen D, Li Y, Yu G (2014).Rapid and simple detection of methicillin-resistance Staphylococcus aureus by orf $X$ loop-mediated isothermal amplification assay. BMC Biotechnol. 14:8.

Sutter VL (1968). Identification of Pseudomonas species isolated from hospital environment and human sources. Appl. Microbiol. 16:15321538.

Uemura N, Makimura K, Onozaki M, Otsuka Y, Shibuya Y, Yazaki H, Kikuchi Y, Abe S, Kudoh S (2008).Development of a loopmediated isothermal amplification method for diagnosing Pneumocystis pneumonia. J. Med. Microbiol. 57(1):50.

Wang Y, Kang Z, Gao H, Gao Y, Qin L, Lin H., Yu, F, Qi X, Wang X (2011). A one-step reverse transcription loop-mediated isothermal amplification for detection and discrimination of infectious bursal disease virus. Virol. J. 8:108.

Weyant RS, Moss CW, Weaver RE, Hollis DG, Jordan JG, Cook EC, Daneshvar MI (1996).Identification of unusual pathogenic gramnegative aerobic and facultatively anaerobic bacteria. 2nd ed. Baltimore, MD: Williams and Wilkins.

Zhao K, Shi W, Han F, Xu Y, Zhu L, Zou Y, Wu X, Zhu H, Tan F, Tao S, Tang $X$ (2011). Specific, simple and rapid detection of porcine circovirus type 2 using the loop-mediated isothermal amplification method. Virol. J. 8:126. 